\title{
Article \\ Moxifloxacin and Sulfamethoxazole-Based Nanocarriers Exhibit Potent Antibacterial Activities
}

\author{
Noor Akbar ${ }^{1,+}{ }^{\dagger}$ Jasra Gul ${ }^{2,+}$, Ruqaiyyah Siddiqui ${ }^{1}\left(\mathbb{D}\right.$, Muhammad Raza Shah ${ }^{2}$ and Naveed Ahmed Khan ${ }^{3, *(\mathbb{C})}$ \\ 1 College of Arts and Sciences, American University of Sharjah, University City, \\ Sharjah 26666, United Arab Emirates; nakbar@aus.edu (N.A.); rsiddiqui@aus.edu (R.S.) \\ 2 International Centre for Chemical and Biological Sciences, H.E.J. Research Institute of Chemistry, \\ University of Karachi, Karachi 75270, Pakistan; jasra.gul123@yahoo.com (J.G.); raza.shah@iccs.edu (M.R.S.) \\ 3 Department of Clinical Sciences, College of Medicine, University of Sharjah, University City, \\ Sharjah 27272, United Arab Emirates \\ * Correspondence: naveed5438@gmail.com; Tel.: +971-6505-7722 \\ + These authors contributed equally to this work.
}

Citation: Akbar, N.; Gul, J.; Siddiqui,

R.; Shah, M.R.; Khan, N.A.

Moxifloxacin and SulfamethoxazoleBased Nanocarriers Exhibit Potent Antibacterial Activities. Antibiotics 2021, 10, 964. https://doi.org/

10.3390/antibiotics10080964

Academic Editor: Raymond J. Turner

Received: 8 July 2021

Accepted: 7 August 2021

Published: 11 August 2021

Publisher's Note: MDPI stays neutral with regard to jurisdictional claims in published maps and institutional affiliations.

Copyright: (c) 2021 by the authors. Licensee MDPI, Basel, Switzerland. This article is an open access article distributed under the terms and conditions of the Creative Commons Attribution (CC BY) license (https:// creativecommons.org/licenses/by/ $4.0 /)$.

\begin{abstract}
Antibiotic resistance is a major concern given the rapid emergence of multiple-drugresistant bacteria compared to the discovery of novel antibacterials. An alternative strategy is enhancing the existing available drugs. Nanomedicine has emerged as an exciting area of research, showing promise in the enhanced development of existing antimicrobials. Herein, we synthesized nanocarriers and loaded these with available clinically approved drugs, namely Moxifloxacin and Sulfamethoxazole. Bactericidal activity against Gram-negative (Serratia marcescens, Pseudomonas aeruginosa, Klebsiella pneumoniae, and Salmonella enterica) and Gram-positive (methicillin-resistant Staphylococcus aureus, Streptococcus pneumoniae, and Bacillus cereus) bacteria was investigated. To characterize the nanocarriers and their drug-loaded forms, Fourier-transform infrared spectroscopy, dynamic light scattering, and atomic force microscopy were utilized. Antibacterial assays and hemolysis assays were carried out. Moreover, lactate dehydrogenase assays were performed to determine cytotoxicity against human cells. The results depicted the successful formation of drug-nanocarrier complexes. The potent antibacterial activities of the drug-loaded nanocarriers were observed and were significantly enhanced in comparison to the drugs alone. Hemolysis and cytotoxicity assays revealed minimal or negligible cytotoxic effects against human red blood cells and human cells. Overall, metronidazole-based nanocarriers loaded with Moxifloxacin and Sulfamethoxazole showed enhanced bactericidal effects against multiple-drug-resistant bacteria compared with drugs alone, without affecting human cells. Our findings show that drug-loaded nanocarriers hold promise as potent chemotherapeutic drugs against multiple-drug-resistant bacteria.
\end{abstract}

Keywords: antibiotic resistance; nanocarriers; Moxifloxacin; Sulfamethoxazole; cytotoxicity; niosomes

\section{Introduction}

The dramatic rise in antibiotic resistance demands the discovery of novel antibacterial agents [1]. In part, this is due to the misuse of antibiotics, which has resulted in the rise of multiple-drug-resistant (MDR) bacteria, which is a growing concern [2,3]. Resistant bacteria such as Staphylococcus aureus, E. coli, and Pseudomonas aeruginosa are some examples. Consequently, there is an urgent need to discover innovative antimicrobial compounds for the treatment of human and animal diseases due to resistant bacteria. In the past few decades, the World Health Organization (WHO) and the Centers for Disease Control and Prevention (CDC) have focused on finding solutions to combat antibiotic resistance [4]. Despite tremendous efforts, the emergence of MDR bacteria is being observed at an alarming pace. Currently, methicillin-resistant Staphylococcus aureus (MRSA), vancomycin-resistant Enterococcus (VRE), Pseudomonas aeruginosa, Acinetobacter baumannii, Escherichia coli, and 
Klebsiella pneumonia present a significant danger to public health, with social repercussions as well as a financial burden. Furthermore, bacteria that instigate food-borne illnesses, acute respiratory infections, and central nervous system and cutaneous infections also remain a major concern for human health. Thus, there is a clear and urgent need to discover novel antibacterials. Nonetheless, an alternative approach is to modify existing drugs to enhance their efficacy [5]. For the latter, several studies have depicted the potential application of nanotechnology against MDR bacteria [6-10]. Nanomaterials have distinctive properties that enable them to be used in biological and material sciences [11]. Nanomaterials (nanoparticles and nanocarriers) are considered safe and can penetrate cells/tissues safely due to their miniature size and increased surface area [12]. Nanocarriers have been used as vehicles for drug delivery. Studies have shown that nanocarriers can increase the bioavailability and therapeutic competence of drugs, while offering better accumulation at the target site $[13,14]$. The loading of drugs within the carrier materials (nanomaterials) can enhance their biological applications, including their antimicrobial activity $[7,15]$.

Moxifloxacin (Mox), being a fluoroquinolone, has revealed an extended spectrum of antibacterial efficacy against pathogenic bacteria [16]. It has remarkable antibacterial efficacy against Gram-positive pathogenic cocci as well as retaining efficacy against Gramnegative bacteria [17]. Similarly, Sulfamethoxazole (Sulp) is a broad-spectrum antibacterial agent that is used currently to treat several bacterial infections [18]. The drug exhibits bacteriostatic effects by producing tetrahydrofolic acid, which is the active form of folic acid. It also arrests the synthesis of purines, thymidine, and bacterial DNA [18].

To determine whether the loading of the abovementioned drugs within nanomaterials can augment antibacterial efficacy, we loaded these drugs within nanocarriers and then tested them for their antibacterial activities using bactericidal experiments. Prior to determining their bioactivity, Fourier-transform infrared (FTIR), atomic force microscopy (AFM), zeta sizer, and zeta potential analysis were carried out to characterize these formulations. Hemolysis and lactate dehydrogenase (LDH) assays were performed to test the cytotoxicity of the drug-loaded nanocarriers against human cells and red blood cells. The loading of existing drugs with nanocarriers enhanced the potency of antibacterial efficacy, with marginal cytotoxic effects against human cells. These outcomes are significant and should encourage the utilization of novel antibacterial compositions in the clinical setting.

\section{Materials and Methods}

\subsection{Synthesis of 2-(2-Methyl-5-nitro-1H-imidazol-1-yl)ethyldecanoate (DC-Met-10)}

Synthesis of DC-Met-10 as outline in below was carried out by using a vigorously stirred solution of Metronidazole ( $500 \mathrm{mg} ; 2.921 \mathrm{mmol}$ ) in $25 \mathrm{~mL}$ acetone, refluxed at $60{ }^{\circ} \mathrm{C}$ for $30 \mathrm{~min}$, followed by adding decanoyl chloride $(0.62 \mathrm{~mL} ; 3 \mathrm{mmol})$. Next, it was refluxed further for $10 \mathrm{~h}$ with constant stirring (Scheme 1). The progression of the reaction was monitored by thin-layer chromatography (TLC). After complete consumption of the starting material, the solvent was evaporated from the reaction mixture after cooling to room temperature. After removing the excess solvent, the reaction mixture was poured into chilled distilled water. The aqueous part was extracted with n-hexane $(3 \times 25 \mathrm{~mL})$, the organic portions were combined, excess hexane was removed through rotary evaporation, and the product was purified by silica gel chromatography with an 8:2 (n-hexane: ethyl acetate) solvent system to obtain gummy liquid with a yield of $76 \%$ (Scheme 1 ). ${ }^{1} \mathrm{H}-\mathrm{NMR}$ (MeOD) ppm: $0.90\left(\mathrm{t}, 3 \mathrm{H}, \mathrm{CH}_{3}, j=4 \mathrm{~Hz}\right), 1.26-1.28\left(\mathrm{~m}, 12 \mathrm{H}, \mathrm{CH}_{2}\right), 1.46-1.54(\mathrm{~m}, 2 \mathrm{H}$, $\left.\mathrm{CH}_{2}\right), 2.2\left(\mathrm{t}, 2 \mathrm{H}, \mathrm{CH}_{2}-\mathrm{CO}, j=7.2 \mathrm{~Hz}\right), 2.50\left(\mathrm{~s}, 3 \mathrm{H}\right.$, Heterocyclic $\left.\mathrm{CH}_{3}\right), 4.42\left(\mathrm{t}, 2 \mathrm{H}, \mathrm{CH}_{2}-\mathrm{N}\right.$, $j=5.2 \mathrm{~Hz}), 4.66\left(\mathrm{t}, 2 \mathrm{H}, \mathrm{CH}_{2}-\mathrm{O}, j=5.2 \mathrm{~Hz}\right), 7.92(\mathrm{~s}, 1 \mathrm{H}$, heterocyclic proton). Using EI-MS, the resultant ion peak appeared at $326.2 \mathrm{~m} / \mathrm{z}$. 


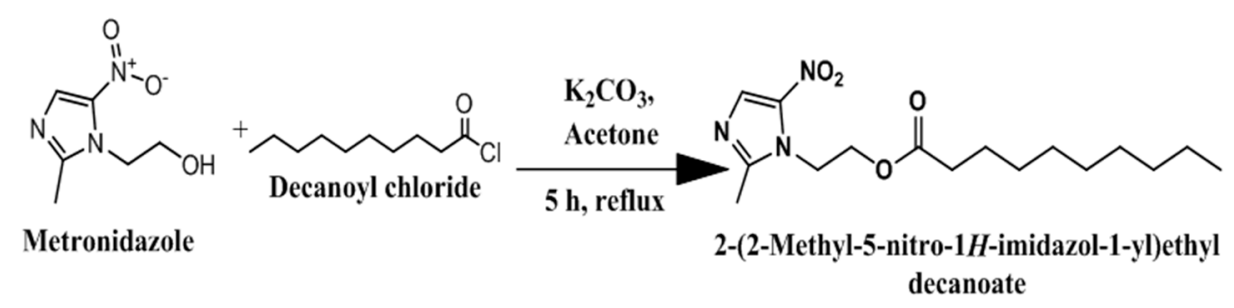

Scheme 1. Scheme of DC-Met-10 synthesis. Preparation of drug-loaded DC-Met-10 niosomal formulation.

Moxifloxacin and Sulfamethoxazole-loaded niosomal vesicle (Mox-Met-Lip and SulMet-Lip) from the synthesized amphiphile (DC-Met-10) was prepared as previously described [19]. Moxifloxacin-loaded niosomal vesicles were prepared by adding DC-Met-10 $(100 \mathrm{mg})$, Moxifloxacin $(100 \mathrm{mg})$, and cholesterol $(50 \mathrm{mg})$ in a round-bottomed flask with $30 \mathrm{~mL}$ of methanol. Similarly, Sulfamethoxazole-loaded niosomal vesicles were prepared by adding DC-Met-10 (100 mg), Sulfamethoxazole (100 mg), and cholesterol (50 mg) in another round-bottomed flask with $30 \mathrm{~mL}$ of methanol, and solvent was evaporated using a rotary evaporator, leading to a thin film of niosomal vesicles. Using $100 \mathrm{~mL}$ of distilled water, these films were rehydrated in a bath sonicator at $30^{\circ} \mathrm{C}$ for approx. $15 \mathrm{~min}$, followed by sonication for $2 \mathrm{~min}$ at $25{ }^{\circ} \mathrm{C}$ with $5 \mathrm{sec}$ on/off cycle to reduce the particle size, and suspensions were kept at $4^{\circ} \mathrm{C}$.

\subsection{Zeta Potential, Size, Polydispersity Index, and Surface Morphology}

Samples were characterized for surface morphology, zeta potential, size, and polydispersity index as described previously $[7,20]$. Using atomic force microscopy (AFM; Agilent 5500; Agilent Technologies, Santa Clara, CA, USA), the shapes of Met-Lip, Mox-Met-Lip, and Sul-Met-Lip were investigated as described earlier [7]. Moreover, techniques such as dynamic light scattering (DLS) using a zeta sizer analyzer were used to analyze the hydrodynamic diameter and PDI of these niosomal vesicles (Mox-Met-Lip, Sul-Met-Lip, and Met-Lip). These formulations were diluted with distilled water prior to determination of size. Zeta sizer dip cells were used to determine zeta potential.

\subsection{Efficiency of Drug Entrapment}

Efficiency of drug entrapment was determined as previously described [19] using a UV-visible spectrophotometer (UV-240, Hitachi U-3200, Tokyo, Japan). Mox-Met-Lip and Sul-Met-Lip formulations of Moxifloxacin and Sulfamethoxazole were spun at 12,000 rpm for $30 \mathrm{~min}$. Pellets containing drug were re-suspended in distilled water and subjected to UV spectrophotometry. Moxifloxacin and Sulfamethoxazole were detected at $293 \mathrm{~nm}$ and $267 \mathrm{~nm}$. The efficiency of drug entrapment was determined as follows: $\mathrm{EE} \%=($ Amount of drug entrapped/Total amount of drug added) $\times 100$.

\subsection{FTIR Spectroscopy}

To analyze the possible interaction of Moxifloxacin (Mox) with formulation excipients, pure Mox, drug excipients (Cholestrol), synthesized amphiphilic molecule (DC-Met-10), and drug-loaded niosomal formulations (Mox-Met-Lip, SUL-Met-Lip, and empty vesicle (Met-Lip)) were mixed with a $\mathrm{KBr}$ disc and pressed to form a self-supporting disk. Spectra were scanned in the range of $400-4000 \mathrm{~cm}^{-1}$ with an IR-470 spectrometer (Shimadzu, Kyoto, Japan) [7].

\subsection{Hemolysis Assay}

To determine the toxic effect of the synthesized amphiphilic compound (DC-Met-10) towards red blood cells, a hemolysis test was performed [21]. Briefly, cells were diluted with sodium citrate as an anti-coagulating agent in a 9:1 ratio and diluted with PBS (2.5 mL) in 1:1.25. Next, doses of DC-Met-10 were added, and samples were kept in water bath at $37^{\circ} \mathrm{C}$ for approx. $30 \mathrm{~min}$, followed by centrifugation at $900 \mathrm{rpm}$ for $5 \mathrm{~min}$. Finally, 
the supernatant was collected and the hemolysis ratio was calculated using a UV-vis spectrophotometer at $545 \mathrm{~nm}$ as follows:

$$
\operatorname{HR}(\%)=\frac{(\mathrm{As}-\mathrm{An})}{(\mathrm{Ap}-\mathrm{An})} \times 100
$$

where (As) is the sample absorbance readout whereas (Ap) and (An) are the positive and negative control absorbance readout, respectively. (Positive control containing $0.2 \mathrm{~mL}$ of blood mixed with $10 \mathrm{~mL}$ of distilled water. Similarly, negative control containing $0.2 \mathrm{~mL}$ of blood mixed with $10 \mathrm{~mL}$ of PBS.)

\subsection{Bacterial Cultures Used in this Study}

Several MDR bacteria were used, including Gram-positive (methicillin-resistant S. aureus (MRSA), B. cereus, and S. pneumoniae) and Gram-negative (P. aeruginosa, S. marcescens, S. enterica, and K. pneumoniae) (Table 1). All bacterial isolates were from clinical samples. These bacteria were grown aerobically in nutrient broth (NB) at $37^{\circ} \mathrm{C}$ overnight preceding experiments, as previously depicted [22,23].

Table 1. Bacteria used in this study.

\begin{tabular}{cc}
\hline Bacterial Isolate & Strain \\
\hline Streptococcus pyogenes & ATCC 49399 (clinical isolate) \\
\hline Methicillin resistant Staphylococcus aureus & MTCC 381123 (clinical isolate) \\
\hline Streptococcus pneumoniae & ATCC 13883 (clinical isolate) \\
\hline Bacillus cereus & MTCC 131621 (clinical isolate) \\
\hline Escherichia coli K1 & MTCC 710859 (clinical isolate) \\
\hline Pseudomonas aeruginosa & ATCC 10145 (clinical isolate) \\
\hline Klebsiella pneumonia & ATCC 13883 (clinical isolate) \\
\hline Serratia marcescens & MTCC 13880 (clinical isolate)
\end{tabular}

\subsection{Antibacterial Assays}

Bactericidal assays were performed to determine the efficacy of drugs and drugloaded nano-formulations against MDR bacteria [22,23]. Briefly, drugs alone, nanocarriers alone, and drug-loaded nanocarriers were kept with $1 \times 10^{6}$ bacteria for $2 \mathrm{~h}$ at $37^{\circ} \mathrm{C}$. Next, ten-fold serial dilutions were accomplished with plating on nutrient agar plates. Plates were kept overnight at $37^{\circ} \mathrm{C}$. Finally, colonies were counted to estimate viable bacterial colony-forming units (c.f.u). For negative controls, bacteria were cultured alone in phosphate-buffered saline (PBS), while for the positive control, bacteria were treated with gentamicin $(100 \mu \mathrm{g} / \mathrm{mL})$.

\subsection{In Vitro Host Cell Cytotoxicity}

To elucidate the cytotoxic effects of drugs, nanocarriers, and drug-loaded nanocarriers, lactate dehydrogenase assays were performed as described earlier [22]. HeLa (Henrietta lacks cervical adenocarcinoma) monolayers were cultivated in 96-well plates up to $80-90 \%$ confluency. After this, monolayers were challenged with drugs alone, nanocarriers alone, and drug-loaded nanocarriers, and plates were placed at $37{ }^{\circ} \mathrm{C}$ at $5 \% \mathrm{CO}_{2}$ and $95 \%$ humidity for $24 \mathrm{~h}$. The following day, Triton X-100 (0.1\%) was incorporated into positive control wells and plates were placed at $37^{\circ} \mathrm{C}$ for $1 \mathrm{~h}$. Subsequently, an equal amount of $\mathrm{LDH}^{\text {Plus }}$ kit reagent (Cytotoxicity Detection kit; Roche Diagnostics, Indianapolis, IN, USA) was mixed with equal volume of cell supernatant containing the enzyme (Lactate Dehydrogenase). HeLa cells in RPMI alone were utilized as negative control. The amount of liberated enzyme from HeLa cells was estimated by the given formula: Percent 
cytotoxicity $=($ value of sample - value of negative control value $) /($ value of positive control - value of negative control) $\times 100$.

\subsection{Statistical Asessment}

For statistical assessment, the Graph Pad Prism software, version 8.0.2 (GraphPad, San Diego, CA, USA), was utilized. T-test (two-tailed distribution) $p$ values were elucidated and $p$ value $\leq 0.05$ was denoted as of statistical significance. The experimental data are depicted as mean \pm standard error.

\section{Results}

3.1. Synthesis of DC-Met-10

Using EI-MS and ${ }^{1} \mathrm{H}-\mathrm{NMR}$, the synthesis of DC-Met-10 was confirmed. As shown in Figure 1, the EI-MS spectra of DC-Met-10 showed a molecular ion peak at $m / z 326.2$, and its ${ }^{1} \mathrm{H}-\mathrm{NMR}$ spectra showed characteristic peaks of terminal methyl protons of three protons at $0.908 \mathrm{ppm}$ as a triplet appeared. At $1.260-1.280 \mathrm{ppm}$, a multiplet of twelve protons of the remaining six methylene groups protons was recorded. At $2.242 \mathrm{ppm}$, a triplet of two protons of the methylene adjacent to carbonyl carbon appeared, and at 1.469-1.541 ppm, a multiplet of two protons of the remaining one methylene adjacent to the methylene of carbonyl carbon was scrutinized. At $2.50 \mathrm{ppm}$, a singlet of three protons of terminal $\mathrm{CH}_{3}$ attached to the heterocyclic aromatic ring was examined. At 4.425 and $4.663 \mathrm{ppm}$, a triplet of three protons of methylene adjacent to nitrogen (a part of the heterocyclic aromatic ring) and a triplet of three protons of methylene adjacent to oxygen were detected, respectively. A singlet of one proton of the heterocyclic aromatic ring was also detected at $7.921 \mathrm{ppm}$ (Figure 2).

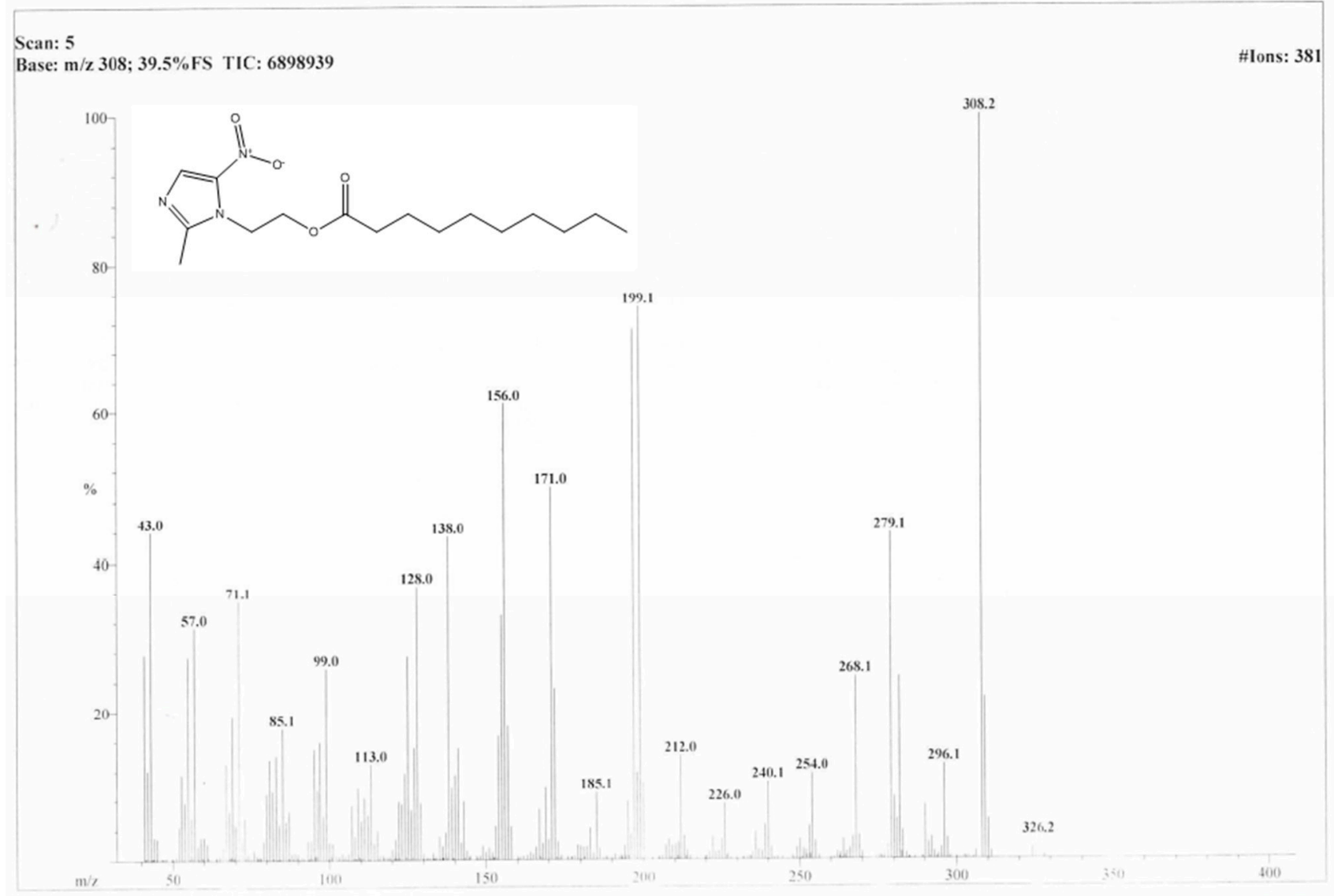

Figure 1. Mass spectra of "DC-Met-10". 


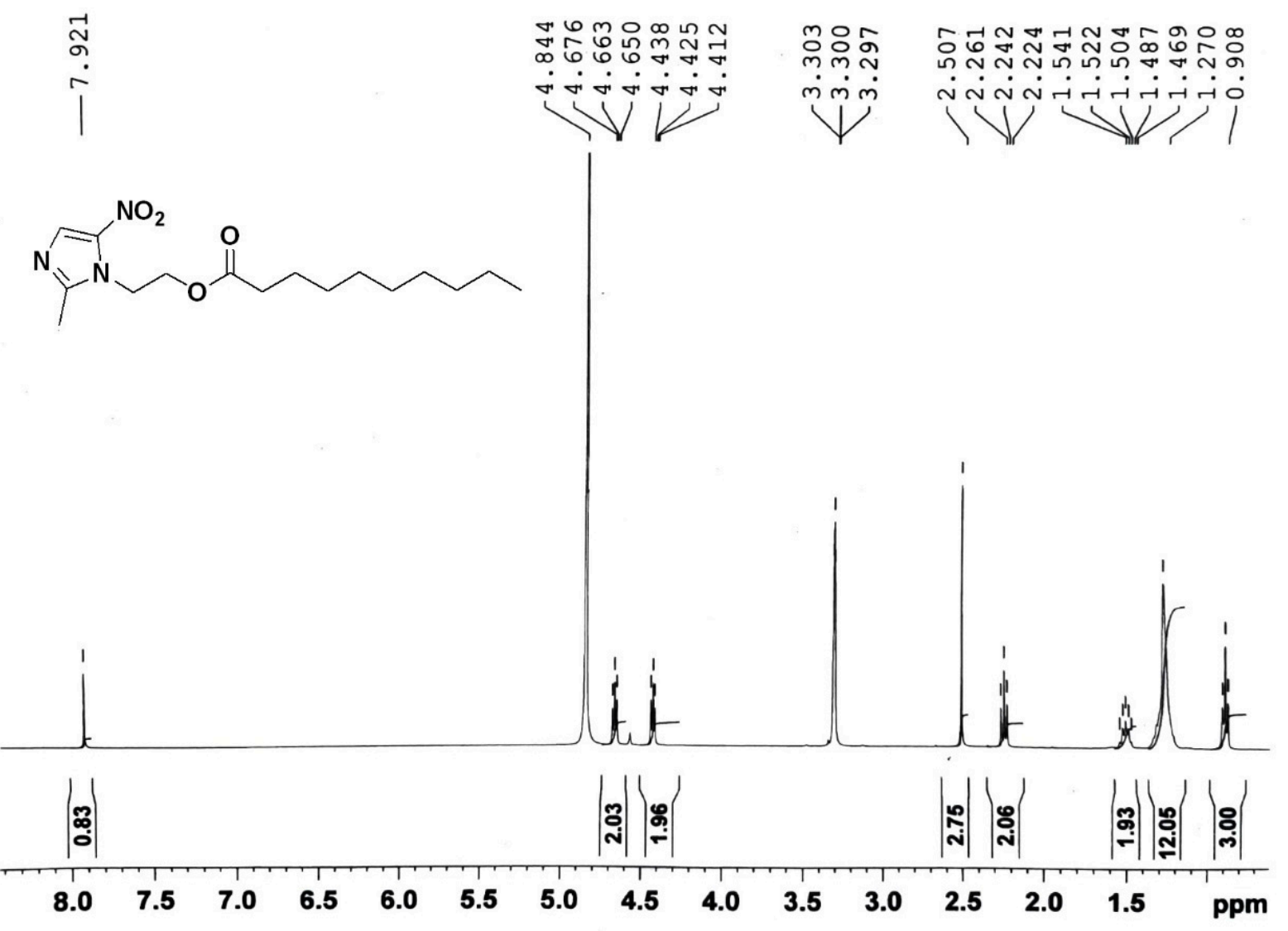

Figure 2. ${ }^{1} \mathrm{H}-\mathrm{NMR}$ spectra of “DC-Met-10".

\subsection{Particle Size, PDI, Zeta Potential, and Surface Morphology}

The results for Met-Lip, MOX-Met-Lip, and SUL-Met-Lip are shown in Table 2. Drugloaded vesicles had greater dispersity and stability, as indicated by their PDI and zeta potential. Interestingly, drug-loaded niosomal carriers were found to be larger in size compared with empty niosomal carriers, which reflects the loading of the drug into the cavities of the vesicles [24]. The morphological evaluation showed that the drug-hosted niosomal vesicles were spherical in shape and the successive loading of the drug into the cavities of vesicles was observed. The morphology of these vesicles is depicted in Figure 3A-C, respectively. Previously, Kaskoos (2014) reported the size of moxifloxacinloaded chitosan-dextran nanoparticles as $279.18 \mathrm{~nm}$, with a good polydispersity index of 0.367 [25]. In another study, Sohrabi et al. (2016) reported the size of chitosan gel-embedded moxifloxacin niosomes to be around $290 \mathrm{~nm}$ [26], suggesting that this formulation has a small size and will show a good therapeutic response in vitro and in vivo.

Table 2. Size, PDI, zeta potential, and encapsulation efficiency of drug-loaded niosomes.

\begin{tabular}{cccccc}
\hline Sample & $\begin{array}{c}\text { Composition } \\
\text { (Compound: } \\
\text { Drug: } \\
\text { Cholesterol) }\end{array}$ & Drug EE\% & $\begin{array}{c}\text { Average } \\
\text { Vesicle Size } \\
\mathbf{( n m )}\end{array}$ & PDI & $\begin{array}{c}\text { Zeta Potential } \\
\text { (mV) }\end{array}$ \\
\hline MOX-Met-Lip & $2: 2: 1$ & $73.45 \pm 2.27$ & $184.7 \pm 3.61$ & $0.375 \pm 0.03$ & $-10.1 \pm 3.32$ \\
\hline SUL-Met-Lip & $2: 2: 1$ & $90.35 \pm 2.51$ & $258.2 \pm 5.64$ & $0.308 \pm 0.023$ & $-14.6 \pm 2.25$ \\
\hline Met-Lip & $2: 0: 0$ & 0.00 & $149.0 \pm 4.45$ & $0.213 \pm 0.032$ & $-12.4 \pm 2.5$ \\
\hline
\end{tabular}



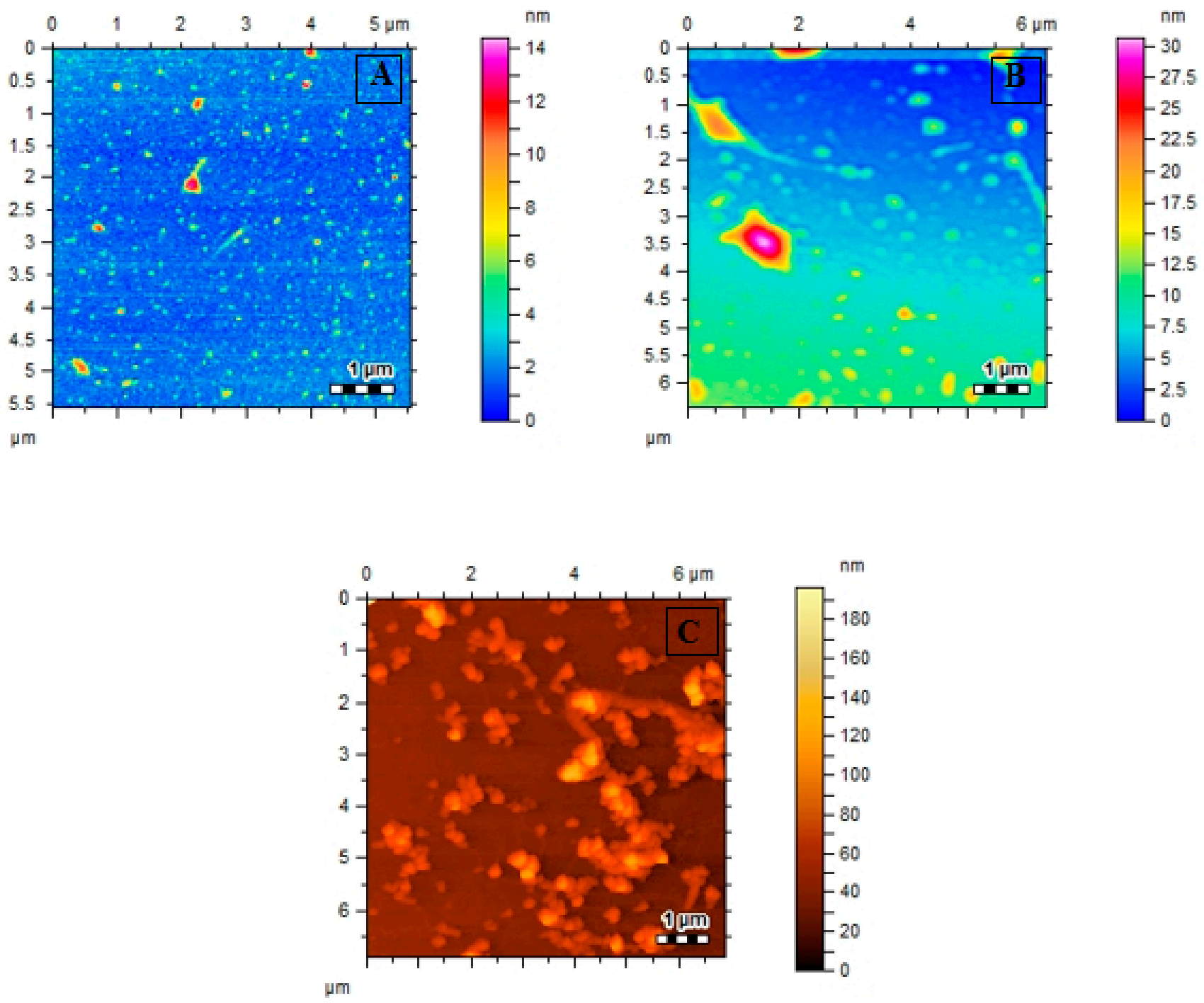

Figure 3. AFM images of (A) Met-Lip, (B) MOX-Met-Lip, (C) SUL-Met-Lip.

\section{3. \% Encapsulation Efficiency of Drug-Loaded Niosomes}

Drug encapsulation efficiency is an important factor as the encapsulated amount of drug in the carriers leads to constant discharge behavior and results in the enhanced bioavailability of pharmacologically active compounds [27,28]. As shown in Table 2, the developed carrier hosted a significant amount of drug and had high encapsulation. The higher encapsulation efficiency and drug-loading behavior of our synthesized non-ionic surfactant makes it a potential candidate for the delivery of active pharmaceutical agents.

\subsection{FTIR Spectroscopy}

FTIR of pure Moxifloxacin (Mox), Sulfamethoxazole (Sulp), cholesterol, synthesized amphiphilic molecule (DC-Met-10), and both drug-loaded niosomal formulations (MoxMet-Lip and Sul-Met-Lip) and also without drug vesicles (Met-Lip) were analyzed and summarized (Figure 4a,b) [29]. In comparison to the drug alone, drug-loaded niosomes showed a slight deviation in IR frequencies, which was due to the induction of secondary interactions posed by non-ionic surfactants (Figure 4a). A broad peak pattern of the hydroxyl group (-OH) appeared at around $3200 \mathrm{~cm}^{-1}$ to $3500 \mathrm{~cm}^{-1}$ in Mox-Met-Lip, whose 
pattern did not appear in any other spectra. Moreover, drug peaks near $1600-1750 \mathrm{~cm}^{-1}$ of $\mathrm{C}=\mathrm{C}$ and $\mathrm{C}=\mathrm{O}$ were found to be suppressed in Mox-Met-Lip, which shows that the peaks had been enhanced in Mox-Met-Lip due to the presence of DC-Met-10 and cholesterol (Figure 4a).

On the other hand, the peaks of Sulfamethoxazole shifted and appeared in the drugloaded niosomal vesicles (Figure $4 \mathrm{~b}$ ). The Sulfamethoxazole peak of $C=C$ that appeared at $1596.3 \mathrm{~cm}^{-1}$ was suppressed in Sul-Met-Lip at $1595.9 \mathrm{~cm}^{-1}$. In the fingerprint region, the drug peak of the C-O bond appeared at $1154.0 \mathrm{~cm}^{-1}$, and also appeared at $1157.2 \mathrm{~cm}^{-1}$ in Sul-Met-Lip (Figure 4b). These interactions give clear evidence about the successive loading of the drug into the cavities of niosomal vesicles and its compatibility within the vesicular system.

a.

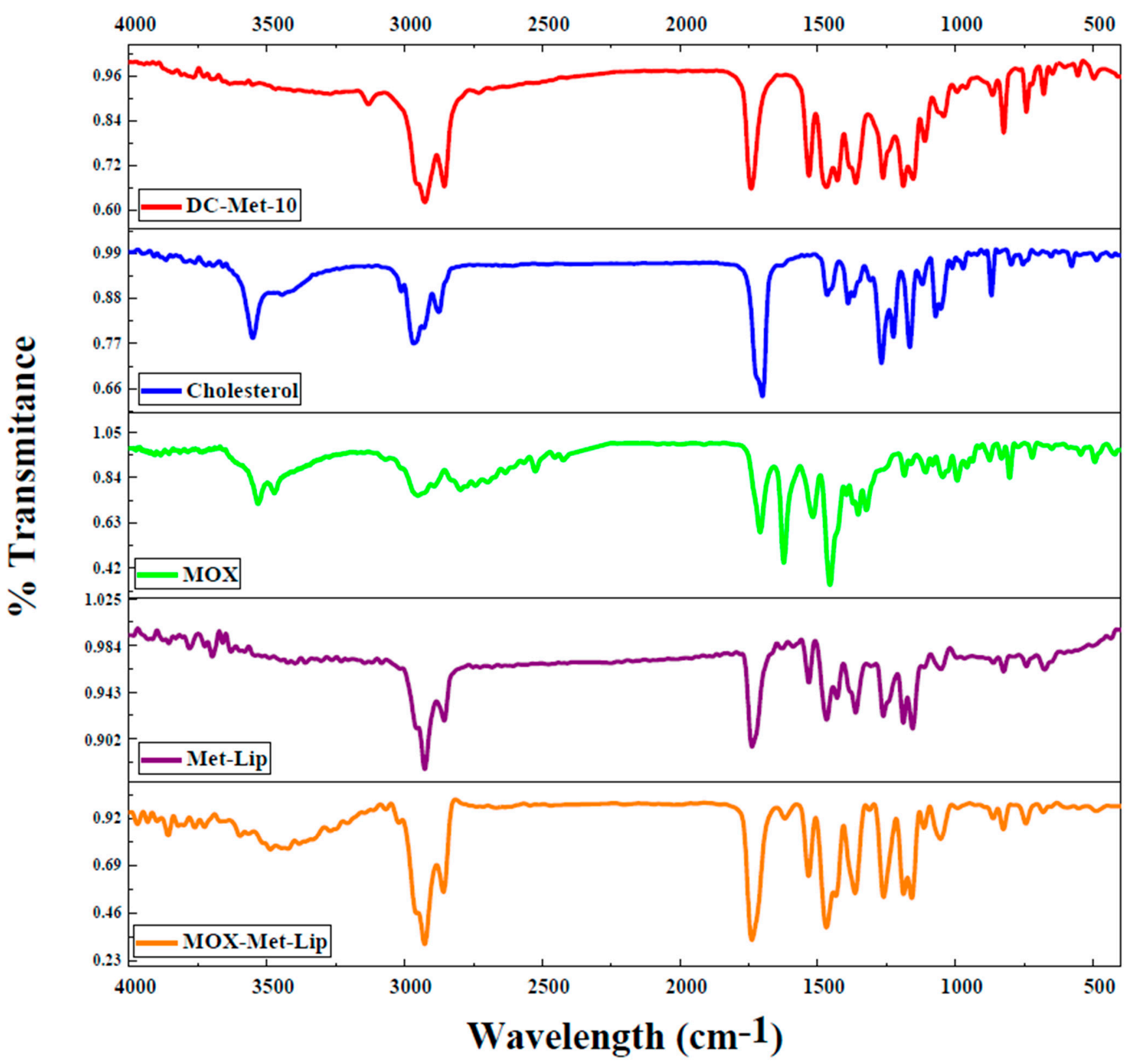

Figure 4. Cont. 
b.

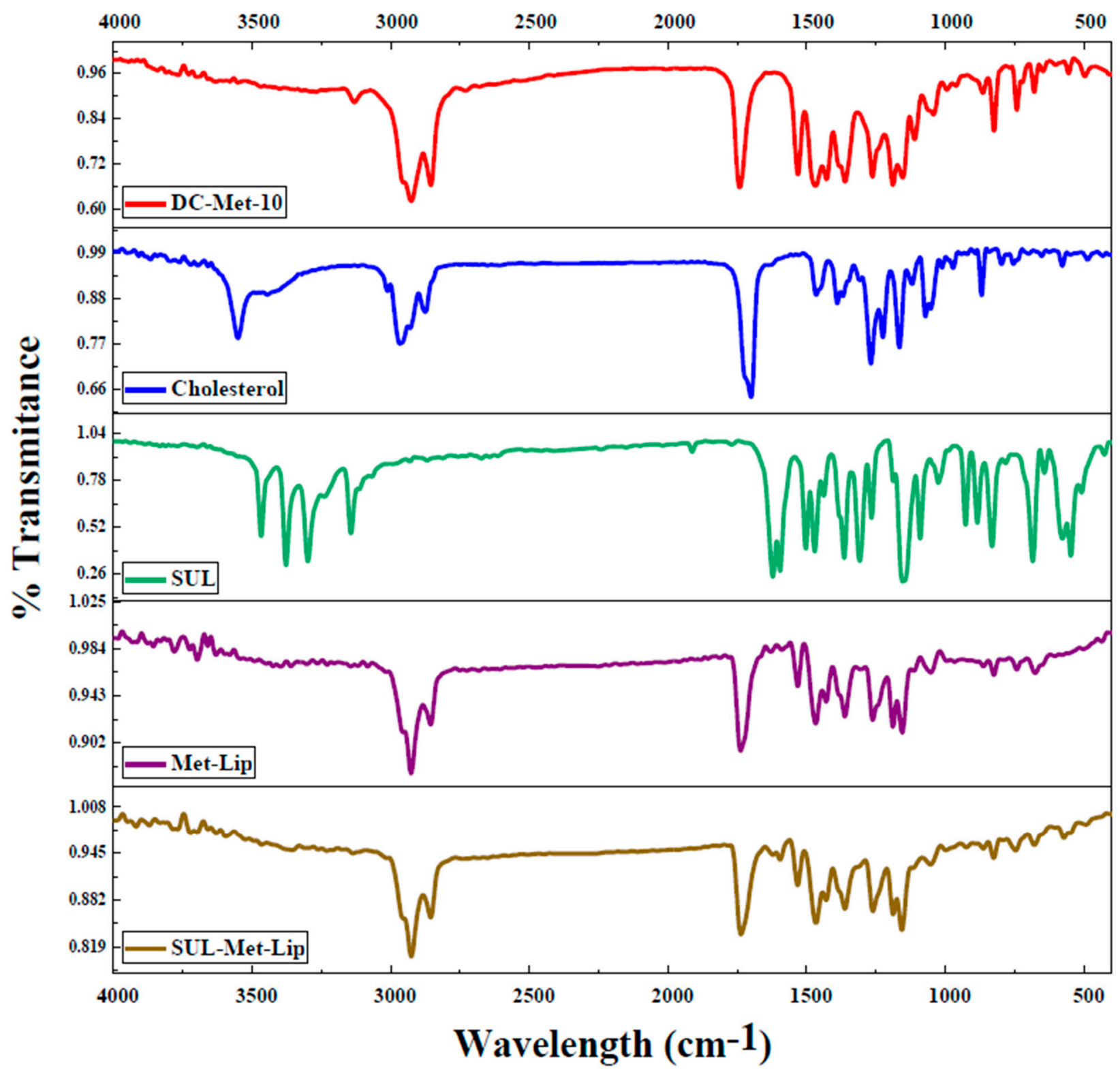

Figure 4. FT-IR spectra of drug-loaded nanocarriers. (a) FTIR of synthesized amphiphilic molecule (DC-Met-10), cholesterol, pure Moxifloxacin (MOX), without drug and drug-loaded vesicles (Met-Lip and MOX-Met-Lip), respectively. (b) FTIR of synthesized amphiphilic molecule (DC-Met-10), cholesterol, pure Sulfamethoxazole (SUL), without drug and drug-loaded vesicles (Met-Lip and SUL-Met-Lip), respectively.

\subsection{Biocompatibility Studies}

Hemolysis studies are considered an important assay of nanocarriers prior to their utilization in drug delivery systems [30]. The percent hemolytic activity was found to be $<10 \%$ at a maximum dose of $2 \mathrm{mg}$ per $\mathrm{mL}$ (Table 3). This suggests that the niosomal carrier is non-hemolytic, and the niosomal carrier, even at higher concentrations, could not disrupt the biological membranes. The hemolytic activity of the niosomal carrier was observed at an accepted level of safety, as shown in Table 3. 
Table 3. Hemocompatibility studies of synthesized amphiphilic molecule (DC-Met-10) at various concentrations ranging from 10 to $2000 \mu \mathrm{g} / \mathrm{mL}$.

\begin{tabular}{cc}
\hline $\begin{array}{c}\text { Concentration of Compounds } \\
(2000 \mu \mathrm{g} / \mathrm{mL})\end{array}$ & Hemolysis (\%) \\
\cline { 2 - 2 } & DC-Met-10 \\
\hline 10 & - \\
\hline 100 & - \\
\hline 250 & - \\
\hline 500 & - \\
\hline 750 & - \\
\hline 1000 & - \\
\hline 1250 & - \\
\hline 1500 & $2.0 \% \pm 0.06 \%$ \\
\hline 1750 & $3.5 \% \pm 0.1 \%$ \\
\hline 2000 & $5.5 \% \pm 0.2 \%$ \\
\hline
\end{tabular}

3.6. Moxifloxacin-and Sulfamethoxazole-Loaded Nanocarrier Presented Potent Antibacterial Efficacy against MDR Bacteria

Nanocarriers, drug alone, and drug-loaded nanocarriers were investigated for their antibacterial efficacy against a panel of MDR clinical isolates. The results demonstrated that the drugs and drug-loaded nanocarriers revealed significant bactericidal activity against Gram-positive MRSA ( $p \leq 0.05$, two-tailed distribution) (Figure 5a). Drug loading in nanocarriers enhanced their bactericidal activity against MRSA when compared with drug alone (Figure 5a). When tested against B. cereus, Moxifloxacin and Moxifloxacinloaded nanocarriers presented exceptional antibacterial properties, with a $100 \%$ killing rate $(p<0.05)$ (Figure $5 b)$. Similarly, Sulfamethoxazole and its counterpart nanocarriers showed significant bacterial killing activity. However, the drug-loaded nanocarriers enhanced the bactericidal effects against B. cereus (Figure 5b). Furthermore, the drugloaded nanocarriers for both drugs remarkably improved the antibacterial efficacy against S. pneumoniae $(p<0.05)$ (Figure $5 c)$.

a.

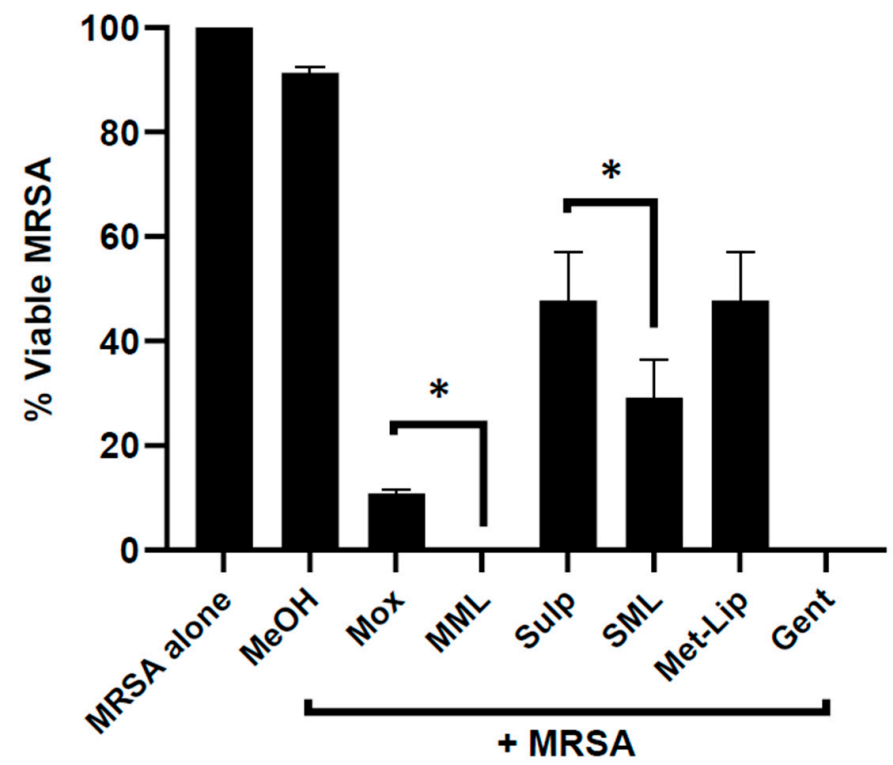

Figure 5. Cont. 
b.

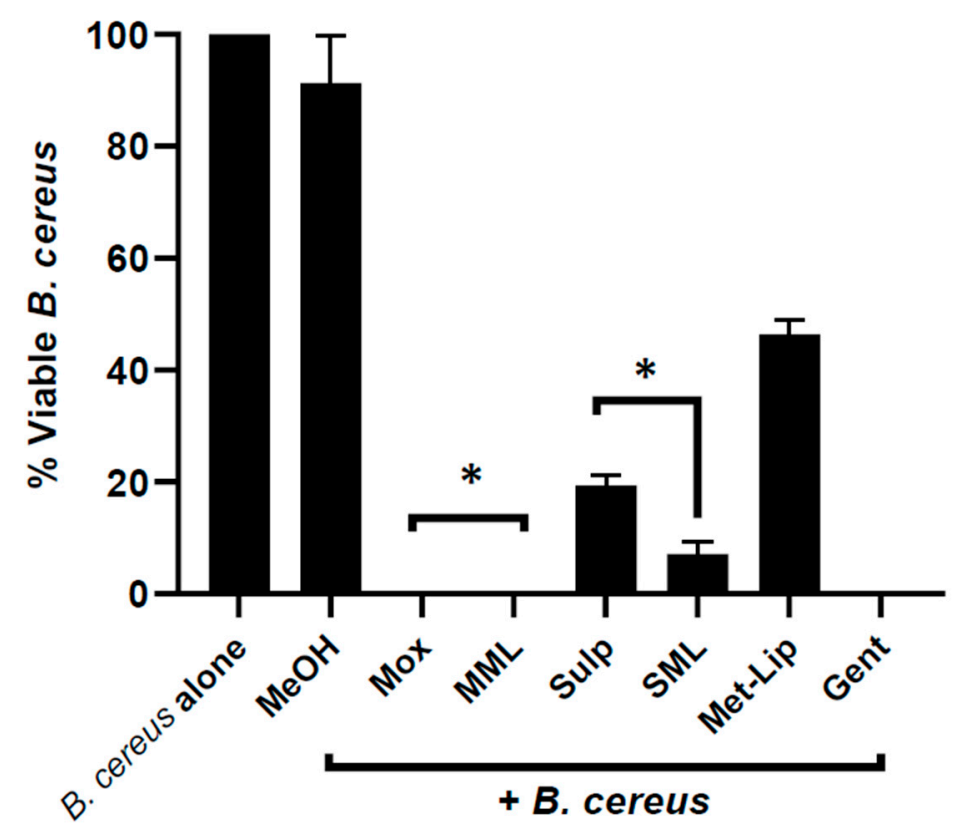

c.

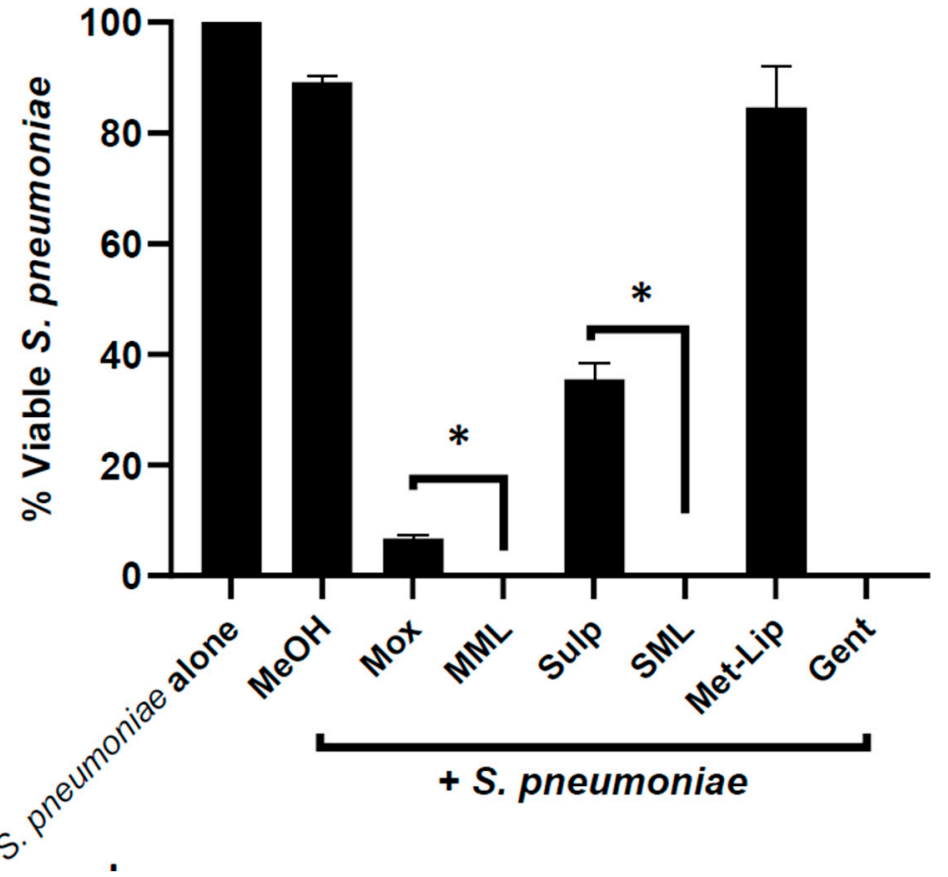

Figure 5. Cont. 
d.

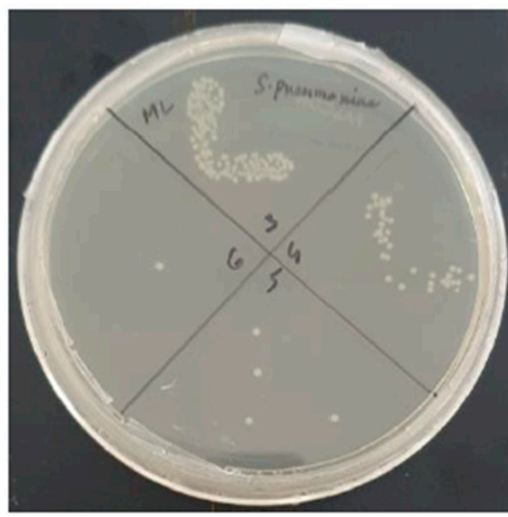

Met-Lip+ S. pneumoniae

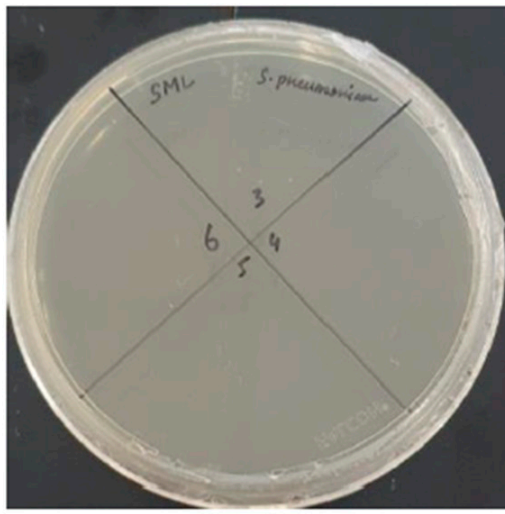

Sul-Met-Lip+ S. pneumoniae

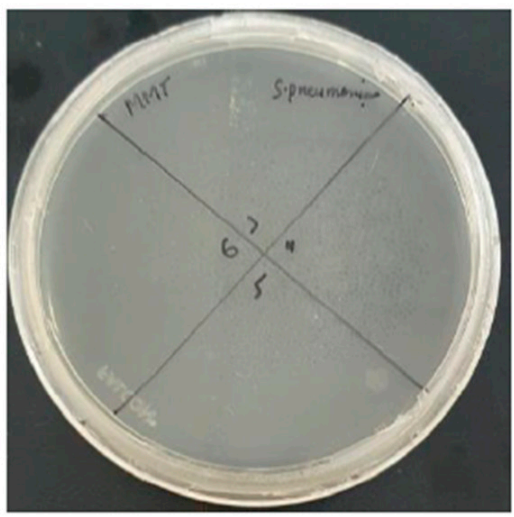

Mox-Met-Lip+ S. pneumoniae

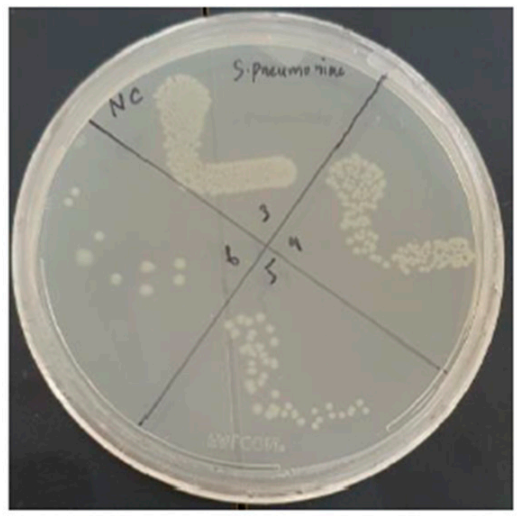

S. pneumoniae alone

Figure 5. Drug-loaded nanocarriers presented significant antibacterial activity against Gram-positive clinical isolates. In brief, drugs and drug-loaded nanocarriers were incubated with one million bacteria at $37^{\circ} \mathrm{C}$ for $2 \mathrm{~h}$, as defined in Materials and Methods. The results showed that drugs and drug-loaded nanocarriers revealed important bactericidal activity against the Gram-positive bacteria. (a) When tested against MRSA, (b) against B. cereus, (c) S. pneumoniae and (d) illustrative effects of S. pneumoniae. Where $\mathrm{MeOH}$ represents methanol, Mox represents Moxifloxacin, MML stands for Moxifloxacin-loaded metronidazole liposomes, Sulp stands for Sulfamethaxazole, SML represents Sulfamethaxazole-loaded metronidazole liposomes, Met-Lip indicates metronidazole liposomes, and Gent represents Gentamicin. The data are expressed as the mean \pm standard error of three independent experimentations performed in duplicate, where ${ }^{*}$ ) represents when $p \leq 0.05$.

Similarly, the drug alone and drug-loaded nanocarriers were evaluated against Gramnegative clinical isolates; the results revealed that the loading of drug in nanocarriers significantly augmented bactericidal efficacy against $P$. aeruginosa $(p<0.05)$ (Figure 6a). In the case of S. marcescens, K. pneumoniae, and S. enterica, both Moxifloxacin and Moxifloxacin-loaded nanocarriers exhibited notable antibacterial activity, while with Sulfamethoxazole, incorporation further improved its bactericidal effects against bacteria $(p<0.05)$ (Figure $6 \mathrm{~b}-\mathrm{d}$ ). 
a.

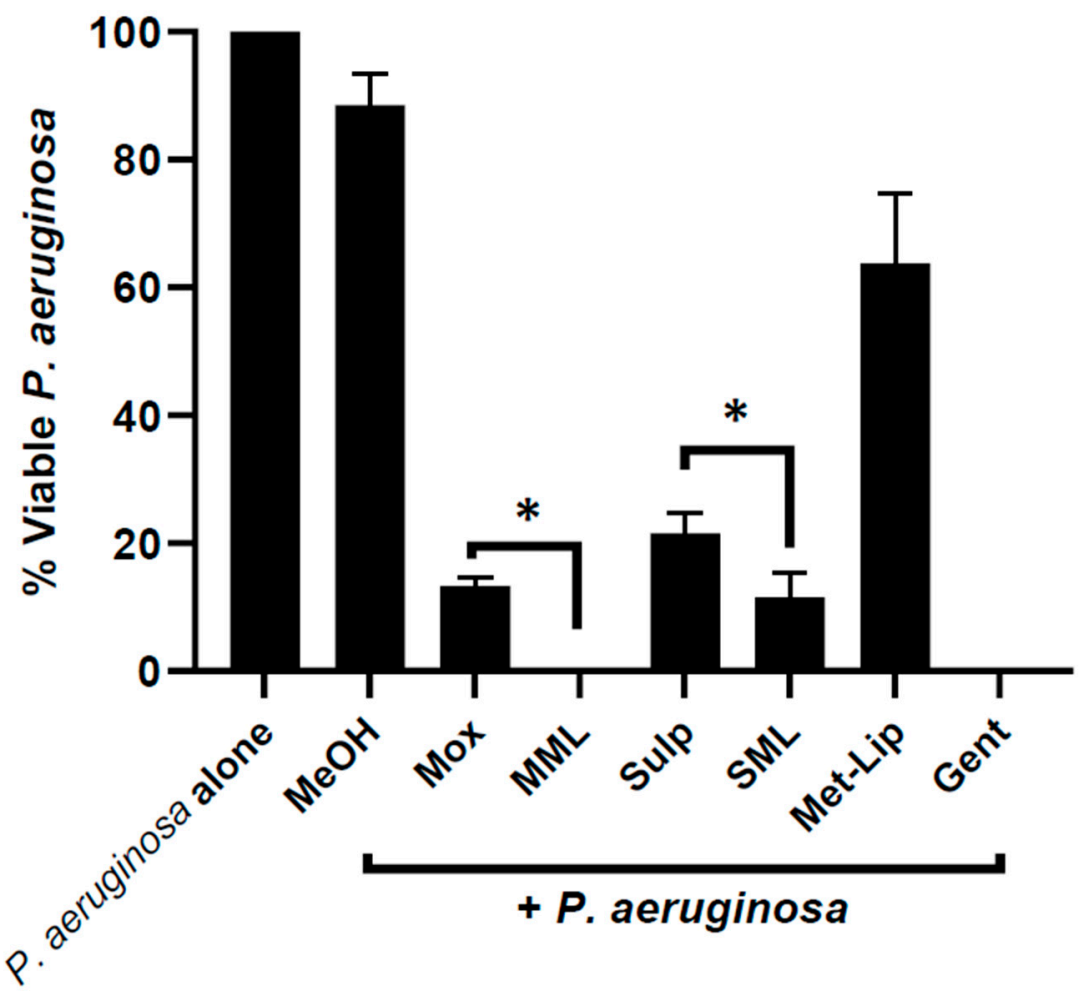

b.

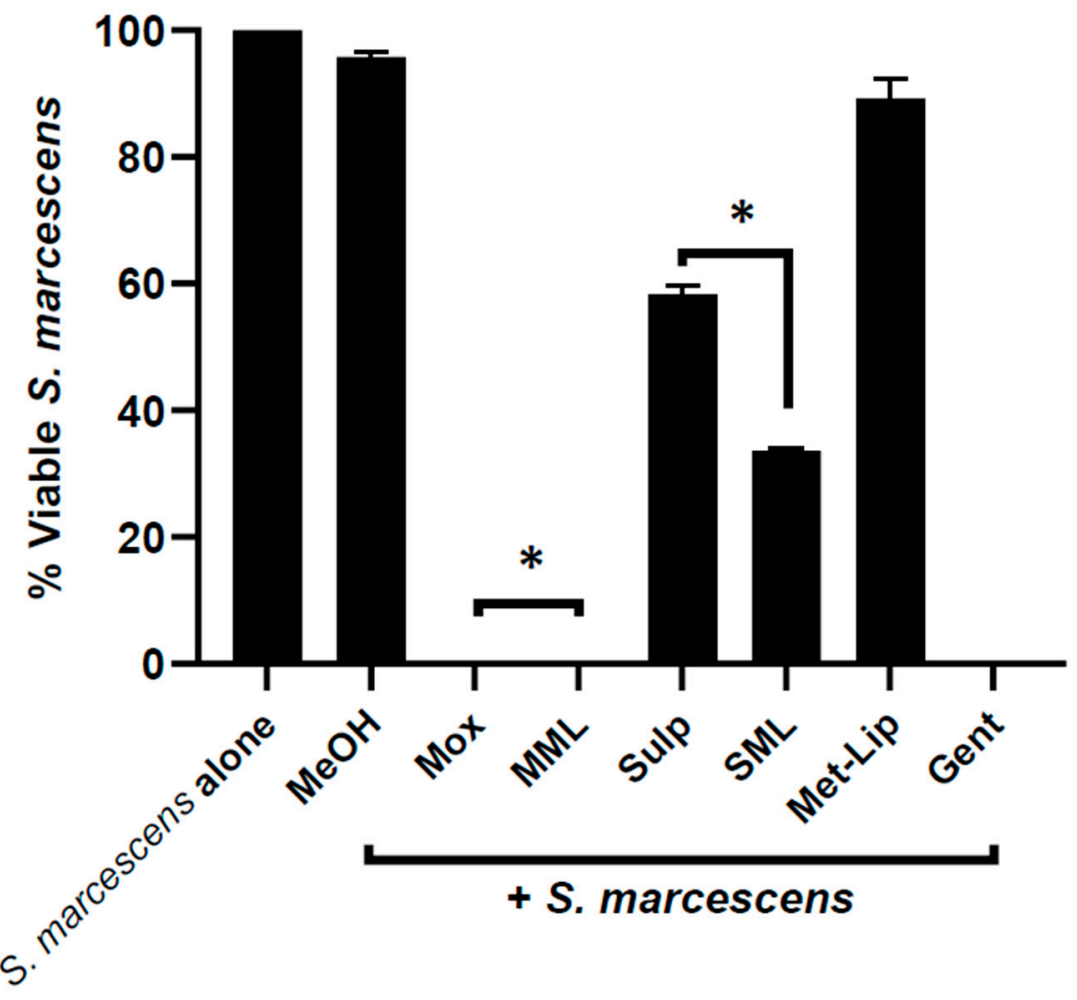

Figure 6. Cont. 

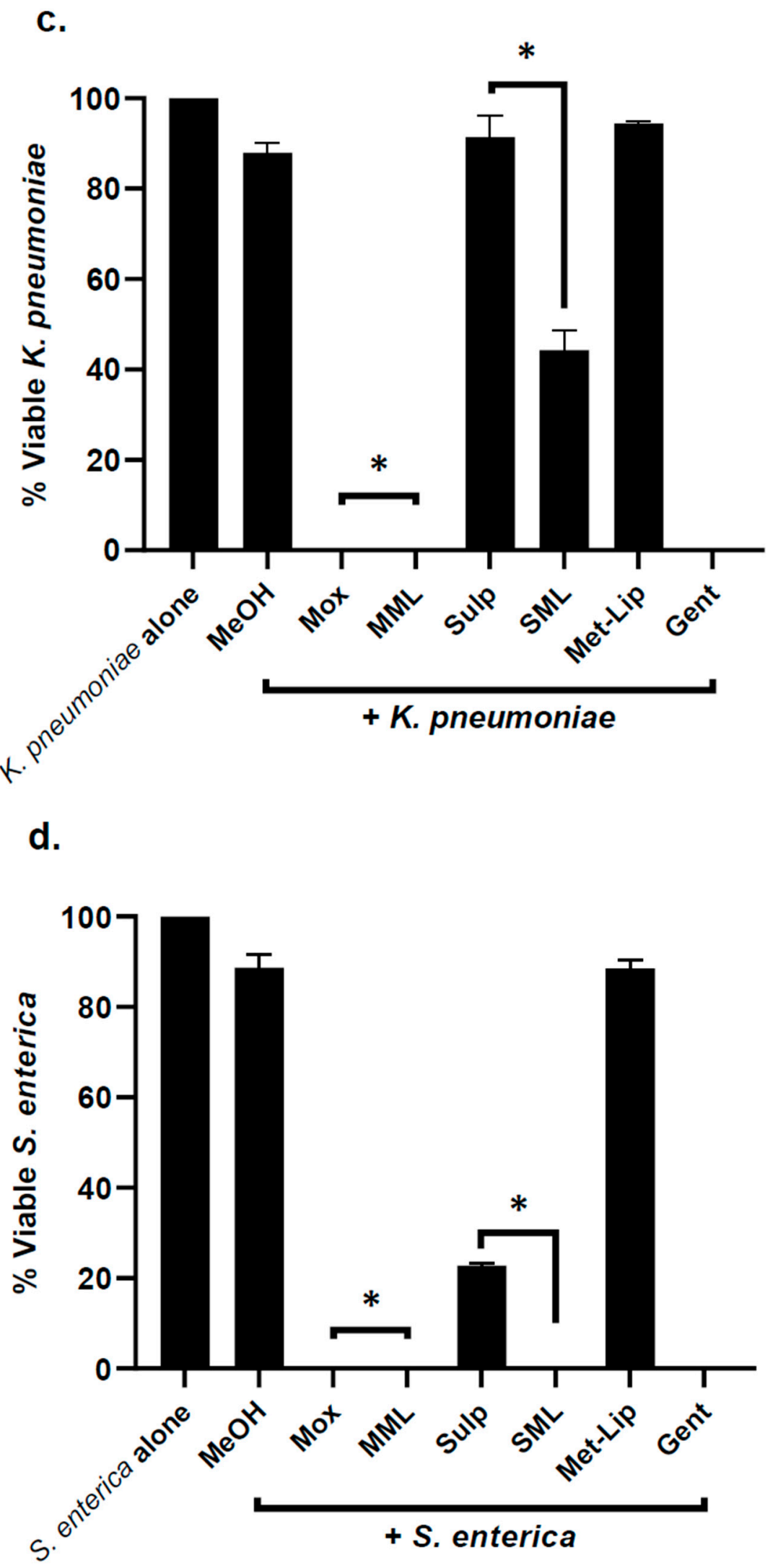

Figure 6. Cont. 
e.

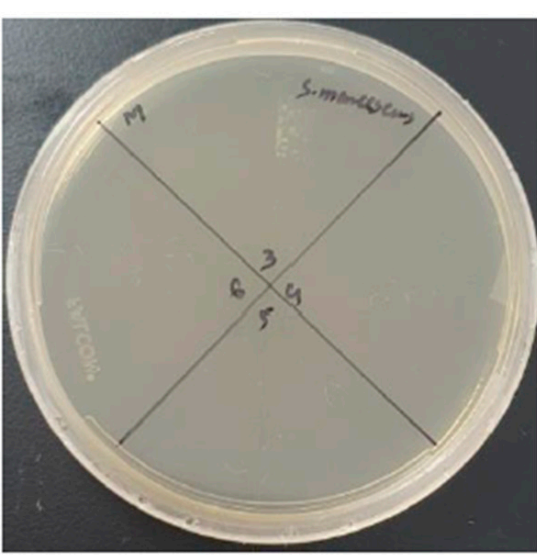

Mox + S. marcescens

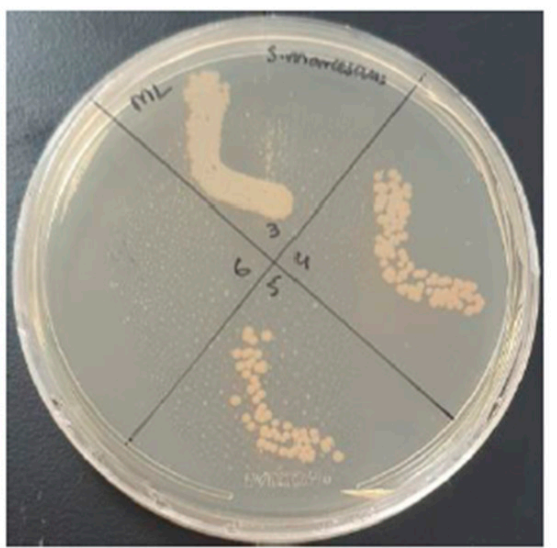

Met-Lip + S. marcescens

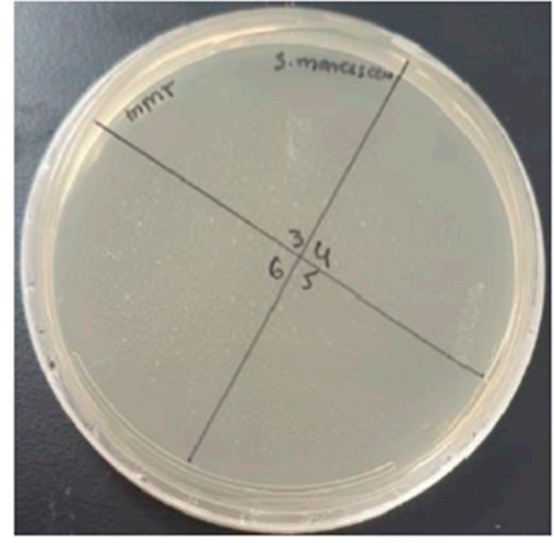

Mox-Met-Lip + S. marcescens

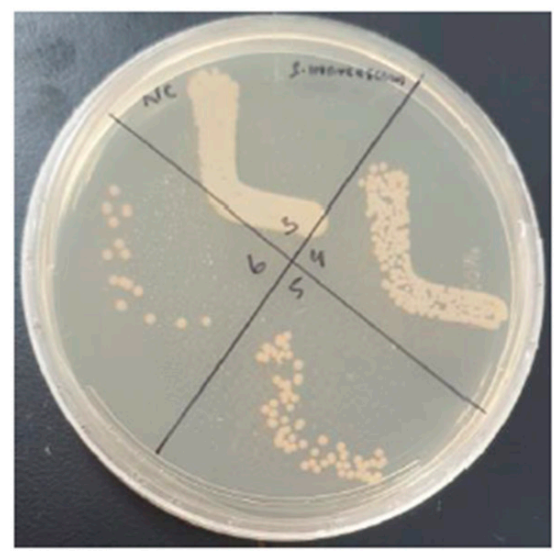

S. marcescens alone

Figure 6. Drugs and their nanocarrier counterparts abolished Gram-negative bacteria. Briefly, bacteria $\left(1 \times 10^{6}\right)$ were challenged with drugs and drug-loaded formulations for $2 \mathrm{~h}$ at $37^{\circ} \mathrm{C}$. Drugs and drug-loaded nanocarriers showed excellent antibacterial effects against Gram-negative bacteria. (a) When tested against P. aeruginosa, (b) against S. marcescens, (c) K. pneumoniae, (d) S. enterica and (e) illustrative effects of $S$. marcescens. Where $\mathrm{MeOH}$ represents methanol, Mox represents Moxifloxacin, MML stands for Moxifloxacin-loaded metronidazole liposomes, Sulp stands for Sulfamethaxazole, SML represents Sulfamethaxazole-loaded metronidazole liposomes, Met-Lip indicates metronidazole liposomes, and Gent represents Gentamicin. The data are expressed as the mean \pm standard error, where ${ }^{*}$ ) represents when $p \leq 0.05$.

\subsection{Moxifloxacin- and Sulfamethoxazole-Loaded Nanocarriers Presented Negligible Cytotoxicity}

Lactate dehydrogenase assays were carried out to assess the cytotoxic effects of the drugs and drug-loaded nanocarriers. The results showed that after overnight incubation with HeLa cells, both the drugs and the drug-loaded counterpart formulations exhibited negligible cytotoxic properties (Figure 7). 


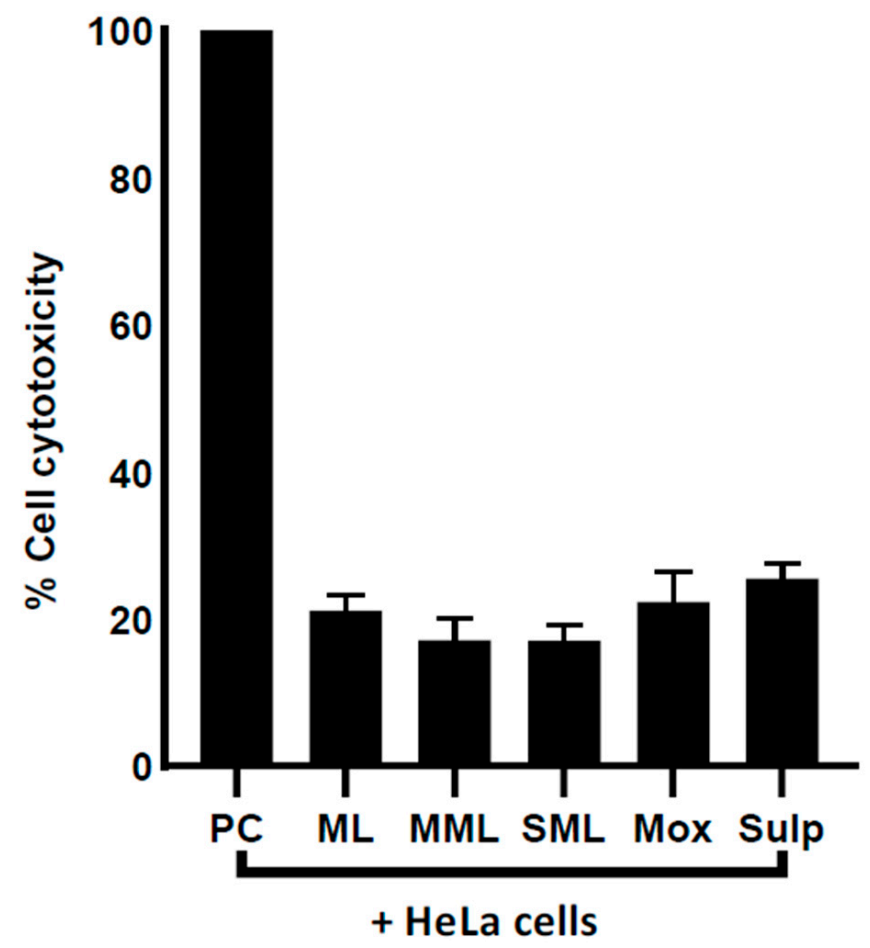

Figure 7. Drugs and drug-loaded nanocarriers demonstrated slight cytotoxic effects against HeLa cells. Human cells were grown in 96-well plate up to $80-90 \%$ confluency, as discussed in Materials and Methods. Next, cell monolayer was treated with drug-nanocarrier combinations overnight at $37{ }^{\circ} \mathrm{C}$ with $5 \% \mathrm{CO}_{2}$ and $95 \%$ humidity. Where ML indicates metronidazole liposomes, MML stands for Moxifloxacin-loaded metronidazole liposomes, SML represents Sulfamethaxazole-loaded metronidazole liposomes, Mox represents Moxifloxacin, Sulp stands for Sulfamethaxazole, and PC represents positive control. The data are expressed as mean \pm standard error. Data were analyzed using Graph Pad Prism software (8.0.2).

\section{Discussion}

The occurrence of multi-drug-resistant bacteria is a significant challenge in the management of infectious diseases [31]. Regardless of advances in clinical practice, the global death rate caused by antibiotic-resistant bacteria has been steadily rising. The "ESKAPE" bacteria (Enterococcus faecium, Staphylococcus aureus, Klebsiella pneumoniae, Acinetobacter baumannii, Pseudomonas aeruginosa, and Enterobacter species), in addition to MDR microbes, are on the rise, making several clinically used antibiotics obsolete against the ESKAPE infections [32]. Antimicrobial resistance is anticipated to cause fatality in more than 10 million people each year by 2050 [33]. This is despite the fact that the reported literature shows significant progress in the development of antibacterial drugs [32]. Antibiotic resistance in bacteria necessitates the development of new remedies to tackle this unprecedented threat. Recent advances in engineering nanoparticles with desired physicochemical features have been hailed as a new line of defense against MDR bacteria [34]. Nanocarriers have been employed to avoid the drawbacks of traditional drug delivery systems, which include, for instance, their non-specificity, burst release, severe side effects, and human cell cytotoxicity [35]. Several types of nanomaterials, such as silver (Ag), copper oxide $(\mathrm{CuO})$, chitosan, gold $(\mathrm{Au})$, iron oxide $\left(\mathrm{Fe}_{3} \mathrm{O}_{4}\right)$, titanium oxide $\left(\mathrm{TiO}_{2}\right)$, zinc oxide $(\mathrm{ZnO})$, fullerenes, NO-releasing NPs, carbon nanotubes (CNTs), and nano-emulsions, are now recognized as strong antibacterial agents [36-42]. In the present study, we loaded clinically approved drugs (Moxifloxacin and Sulfamethoxazole) with metronidazole-based nanocarriers and characterized them using FTIR, DLS, and AFM techniques [43-45]. Next, their bactericidal effects were assessed versus a panel of Gram-negative and Gram-positive MDR clinical isolates. Chemically synthesized silver/chitosan nanocomposite films loaded 
with Moxifloxacin exhibited broad-spectrum antibacterial efficacy against $P$. aeruginosa and S. aureus. This is consistent with recent studies that showed that chitosan-pullulan-silver nanocomposite films loaded with Moxifloxacin revealed antibacterial efficacies against clinical MRSA and P. aeruginosa [45]. An innovative $\mathrm{CuFe}_{2} \mathrm{O} 4$ silica-based nanocomposite loaded with Sulfamethoxazole showed extraordinary antibacterial efficacy against $S$. aureus and E. coli [46]. Szabó et al. (2018) demonstrated the antibacterial effects of a Moxifloxacin$\beta$-cyclodextrin complex versus Gram-negative and Gram-positive bacteria. The complex presented significant bacteria-killing properties [17]. Lignin-based silver nanoparticles depicted notable antibacterial activity against E. coli and S. aureus [9].

Remarkably, Moxifloxacin and Sulfamethoxazole-based nanocarriers presented minimal cytotoxicity and hemolysis effects against HeLa and red blood cells, respectively. Our findings are consistent with previously published data. For instance, silver nanoparticles loaded with lignin showed negligible cytotoxic properties against human cells [9]. Similarly, cinnamic acid-based gold nanoparticles showed minimal cytotoxic properties against human cells [7]. Aseichev et al. (2014) showed that gold nanoparticles did not exhibit hemolysis effects against erythrocytes [47]. Another study revealed that magnetic $\mathrm{Fe}_{3} \mathrm{O}_{4}$ nanoparticles show cytotoxicity versus MCF-7 cells but do not show hemolysis activity against rabbit blood cells [30]. In conclusion, the current study showed that metronidazolebased nanocarriers loaded with Moxifloxacin and Sulfamethoxazole demonstrated notable bactericidal efficacies against MDR Gram-negative and Gram-positive pathogenic bacteria. Moreover, drug-loaded nanocarriers revealed minimal cytotoxic properties against human cells, with no hemolysis activity against human red blood cells, suggesting their probable applications as active chemotherapeutic drugs against MDR-resistant bacterial infections. Future in vivo studies, followed by clinical trials comprising drug-loaded nanoformulations, are warranted to realize these prospects and lead to the availability of much needed novel antimicrobials.

\section{Conclusions}

In summary, here, we tested Moxifloxacin and Sulfamethaxazole alone as well as loaded with metronidazole liposome nanocarriers for their antibacterial activity against several Gram-positive and Gram-negative MDR clinical isolates. Drugs alone and drugloaded nanocarriers showed promising antibacterial effects against MDR bacteria. When compared to drugs alone, metronidazole-based nanocarriers coupled with Moxifloxacin and Sulfamethoxazole demonstrated improved bactericidal activity against numerous MDR bacteria without harming human cell lines. These findings are noteworthy and should lead to the development of new antibacterial medications with improved bioactivity. In future, such drug-loaded nanocarriers with profound antibacterial properties could be investigated in vivo utilizing a mouse/rat animal model.

Author Contributions: R.S. and N.A.K. conceived the study and did discussion with M.R.S. N.A., J.G. conducted all experiments, and data analysis under the supervision of R.S., N.A.K. and M.R.S. N.A. and J.G. wrote the first draft of the manuscript. R.S. and N.A.K. finalized the manuscript. All authors read and approved the final manuscript.

Funding: This research was funded by the American University of Sharjah and University of Sharjah.

Data Availability Statement: The data presented in this study are available on request from the corresponding author.

Conflicts of Interest: The authors declare no conflict of interest.

\section{References}

1. Li, B.; Webster, T.J. Bacteria antibiotic resistance: New challenges and opportunities for implant-associated or-thopedic infections. J. Orthop. Res. 2018, 36, 22-32. [CrossRef]

2. Khameneh, B.; Diab, R.; Ghazvini, K.; Bazzaz, B.S.F. Breakthroughs in bacterial resistance mechanisms and the potential ways to combat them. Microb. Pathog. 2016, 95, 32-42. [CrossRef] [PubMed]

3. Munita, J.M.; Arias, C.A. Mechanisms of antibiotic resistance. Microbiol. Spectr. 2016, 4, 481-511. [CrossRef] 
4. Nathan, C.; Cars, O. Antibiotic Resistance-Problems, Progress, and Prospects. N. Engl. J. Med. 2014, 371, 1761-1763. [CrossRef]

5. Masri, A.; Anwar, A.; Khan, N.A.; Siddiqui, R. The Use of Nanomedicine for Targeted Therapy against Bacterial Infections. Antibiotics 2019, 8, 260. [CrossRef]

6. Agarwal, H.; Menon, S.; Kumar, S.V.; RajeshKumar, S. Mechanistic study on antibacterial action of zinc oxide nanoparticles synthesized using green route. Chem. Interact. 2018, 286, 60-70. [CrossRef] [PubMed]

7. Anwar, A.; Masri, A.; Rao, K.; Rajendran, K.; Khan, N.; Shah, M.R.; Siddiqui, R. Antimicrobial activities of green synthesized gums-stabilized nanoparticles loaded with flavonoids. Sci. Rep. 2019, 9, 3122. [CrossRef]

8. Erjaee, H.; Rajaian, H.; Nazifi, S. Synthesis and characterization of novel silver nanoparticles using Chamaemelumnobile extract for antibacterial application. Adv. Nat. Sci. Nanosci. Nanotechnol. 2017, 8, 025004. [CrossRef]

9. Li, M.; Jiang, X.; Wang, D.; Xu, Z.; Yang, M. In situ reduction of silver nanoparticles in the lignin based hydrogel for enhanced antibacterial application. Colloids Surf. B Biointerfaces 2019, 177, 370-376. [CrossRef]

10. Yin, I.X.; Zhang, J.; Zhao, I.S.; Mei, M.L.; Li, Q.; Chu, C.H. The Antibacterial Mechanism of Silver Nanoparticles and Its Application in Dentistry. Int. J. Nanomed. 2020, 15, 2555-2562. [CrossRef]

11. Kesharwani, P.; Gorain, B.; Low, S.Y.; Tan, S.A.; Ling, E.C.S.; Lim, Y.K.; Chin, C.M.; Lee, P.Y.; Lee, C.M.; Ooi, C.H.; et al. Nanotechnology based approaches for anti-diabetic drugs delivery. Diabetes Res. Clin. Pract. 2018, 136, 52-77. [CrossRef]

12. Leonida, M.D.; Kumar, I. Nanoparticles, Nanomaterials and Nanocarriers. In Bionanomaterials for Skin Regeneration; Springer: Cham, Switzerland, 2016; pp. 37-46.

13. Mura, S.; Nicolas, J.; Couvreur, P. Stimuli-responsive nanocarriers for drug delivery. Nat. Mater. 2013, 12, 991-1003. [CrossRef]

14. Neubert, R.H. Potentials of new nanocarriers for dermal and transdermal drug delivery. Eur. J. Pharm. Biopharm. 2011, 77, 1-2. [CrossRef]

15. Masri, A.; Anwar, A.; Ahmed, D.; Siddiqui, R.B.; Raza Shah, M.; Khan, N.A. Silver nanoparticle conjuga-tion-enhanced antibacterial efficacy of clinically approved drugs cephradine and vildagliptin. Antibiotics 2018, 7, 100. [CrossRef]

16. Balfour, J.A.B.; Lamb, H.M. Moxifloxacin. Drugs 2000, 59, 115-139. [CrossRef]

17. Szabó, Z.I.; Deme, R.; Mucsi, Z.; Rusu, A.; Mare, A.D.; Fiser, B.; Toma, F.; Sipos, E.; Tóth, G. Equilibrium, structural and antibacterial characterization of moxifloxacin- $\beta$-cyclodextrin complex. J. Mol. Struct. 2018, 1166, 228-236. [CrossRef]

18. Masters, P.A.; O’Bryan, T.A.; Zurlo, J.; Miller, D.Q.; Joshi, N. Trimethoprim-Sulfamethoxazole Revisited. Arch. Intern. Med. 2003, 163, 402-410. [CrossRef] [PubMed]

19. Ai, X.; Zhong, L.; Niu, H.; He, Z. Thin-film hydration preparation method and stability test of DOX-loaded di-sulfide-linked polyethylene glycol 5000-lysine-di-tocopherol succinate nanomicelles. Asian J. Pharm. Sci. 2014, 9, 244-250. [CrossRef]

20. Anwar, A.; Rajendran, K.; Siddiqui, R.; Shah, M.R.; Khan, N.A. Clinically Approved Drugs against CNS Diseases as Potential Therapeutic Agents To Target Brain-Eating Amoebae. ACS Chem. Neurosci. 2018, 10, 658-666. [CrossRef]

21. Tsamesidis, I.; Pouroutzidou, G.K.; Lymperaki, E.; Kazeli, K.; Lioutas, C.B.; Christodoulou, E.; Perio, P.; Reybier, K.; Pantaleo, A.; Kontonasaki, E. Effect of ion doping in silica-based nanoparticles on the hemolytic and oxidative activity in contact with human erythrocytes. Chem. Interact. 2020, 318, 108974. [CrossRef] [PubMed]

22. Akbar, N.; Khan, N.A.; Sagathevan, K.; Iqbal, M.; Tawab, A.; Siddiqui, R. Gut bacteria of Cuora amboinensis (turtle) produce broad-spectrum antibacterial molecules. Sci. Rep. 2019, 9, 1-19. [CrossRef]

23. Akbar, N.; Siddiqui, R.; Iqbal, M.; Sagathevan, K.; Kim, K.S.; Habib, F.; Khan, N.A. Gut Bacteria of Rattus rattus (Rat) Produce Broad-Spectrum Antibacterial Lipopeptides. ACS Omega 2021, 6, 12261-12273. [CrossRef] [PubMed]

24. Griffin, B.T.; Guo, J.; Presas, E.; Donovan, M.D.; Alonso, M.J.; O’Driscoll, C.M. Pharmacokinetic, pharmacody-namic and biodistribution following oral administration of nanocarriers containing peptide and protein drugs. Adv. Drug Deliv. Rev. 2016, 106, 367-380. [CrossRef] [PubMed]

25. Kaskoos, R. Investigation of moxifloxacin loaded chitosan-dextran nanoparticles for topical instillation into eye: In-vitro and ex-vivo evaluation. Int. J. Pharm. Investig. 2014, 4, 164-173. [CrossRef]

26. Sohrabi, S.; Haeri, A.; Mahboubi, A.; Mortazavi, A.; Dadashzadeh, S. Chitosan gel-embedded moxifloxacin niosomes: An efficient antimicrobial hybrid system for burn infection. Int. J. Biol. Macromol. 2016, 85, 625-633. [CrossRef]

27. Imran, M.; Shah, M.R.; Ullah, F.; Ullah, S.; Sadiq, A.; Ali, I.; Ahmed, F.; Nawaz, W. Double-tailed acyl glycoside niosomal nanocarrier for enhanced oral bioavailability of Cefixime. Artif. Cells Nanomed. Biotechnol. 2016, 45, 1440-1451. [CrossRef]

28. Tavano, L.; Aiello, R.; Ioele, G.; Picci, N.; Muzzalupo, R. Niosomes from glucuronic acid-based surfactant as new carriers for cancer therapy: Preparation, characterization and biological properties. Colloids Surf. B Biointerfaces 2014, 118, 7-13. [CrossRef] [PubMed]

29. Alemi, A.; Reza, J.Z.; Haghiralsadat, F.; Jaliani, H.Z.; Karamallah, M.H.; Hosseini, S.A.; Karamallah, S.H. Paclitaxel and curcumin coadministration in novel cationic PEGylated niosomal formulations exhibit enhanced synergistic antitumor efficacy. J. Nanobiotechnol. 2018, 16, 28. [CrossRef]

30. Chen, D.-Z.; Tang, Q.; Li, X.; Zhou, X.; Zang, J.; Xiang, J.-Y.; Guo, C.-Q.; Xue, W.-Q. Biocompatibility of magnetic Fe3O4 nanoparticles and their cytotoxic effect on MCF-7 cells. Int. J. Nanomed. 2012, 7, 4973-4982. [CrossRef]

31. Siddiqui, R.; Khan, N.A. Infection control strategy by killing drug-resistant bacteria. Pathog. Glob. Heal. 2013, 107, 215216. [CrossRef]

32. Peraman, R.; Sure, S.K.; Dusthackeer, V.A.; Chilamakuru, N.B.; Yiragamreddy, P.R.; Pokuri, C.; Kutagulla, V.K.; Chinni, S. Insights on recent approaches in drug discovery strategies and untapped drug targets against drug re-sistance. Future J. Pharm. Sci. 2021, $7,1-25$. 
33. World Health Organization (WHO). New Report Calls for Urgent Action to Avert Antimicrobial Resistance Crisis; WHO: Geneva, Swizerland, 2019; Available online: https:/ / www.who.int/news-room/detail/29-04-2019-new-report-calls-for-urgent-action-toavert-antimicrobial-resistance-crisis (accessed on 9 June 2021).

34. Singh, R.; Smitha, M.S.; Singh, S.P. The Role of Nanotechnology in Combating Multi-Drug Resistant Bacteria. J. Nanosci. Nanotechnol. 2014, 14, 4745-4756. [CrossRef]

35. Din, F.U.; Aman, W.; Ullah, I.; Qureshi, O.S.; Mustapha, O.; Shafique, S.; Zeb, A. Effective use of nanocarriers as drug delivery systems for the treatment of selected tumors. Int. J. Nanomed. 2017, 12, 7291-7309. [CrossRef]

36. Chamundeeswari, M.; Sobhana, S.S.L.; Jacob, J.; Kumar, M.G.; Devi, M.P.; Sastry, T.P.; Mandal, A.B. Preparation, characterization and evaluation of a biopolymeric gold nanocomposite with antimicrobial activity. Biotechnol. Appl. Biochem. 2010, 55, 29-35. [CrossRef]

37. Dong, A.; Lan, S.; Huang, J.; Wang, T.; Zhao, T.; Xiao, L.; Wang, W.; Zheng, X.; Liu, F.; Gao, G.; et al. Modifying Fe3O4Functionalized Nanoparticles with N-Halamine and Their Magnetic/Antibacterial Properties. ACS Appl. Mater. Interfaces 2011, 3 , 4228-4235. [CrossRef]

38. Fang, J.; Lyon, D.; Wiesner, M.R.; Dong, A.J.; Alvarez, P. Effect of a Fullerene Water Suspension on Bacterial Phospholipids and Membrane Phase Behavior. Environ. Sci. Technol. 2007, 41, 2636-2642. [CrossRef]

39. Hajipour, M.J.; Fromm, K.M.; Ashkarran, A.A.; de Aberasturi, D.J.; de Larramendi, I.R.; Rojo, T.; Serpooshan, V.; Parak, W.J.; Mahmoudi, M. Antibacterial properties of nanoparticles. Trends Biotechnol. 2012, 30, 499-511. [CrossRef] [PubMed]

40. Mukheem, A.; Muthoosamy, K.; Manickam, S.; Sudesh, K.; Shahabuddin, S.; Saidur, R.; Akbar, N.; Sridewi, N. Fabrication and characterization of an electrospun PHA/graphene silver nanocomposite scaffold for antibacterial appli-cations. Materials 2018, 11, 1673. [CrossRef] [PubMed]

41. Mukheem, A.; Shahabuddin, S.; Akbar, N.; Miskon, A.; Sarih, N.M.; Sudesh, K.; Khan, N.A.; Saidur, R.; Sridewi, N. Boron Nitride Doped Polyhydroxyalkanoate/Chitosan Nanocomposite for Antibacterial and Biological Applications. Nanomaterials $2019,9,645$. [CrossRef] [PubMed]

42. Uğur, Ş.S.; Sarışık, M.; Aktaş, A.H.; Uçar, M.Ç.; Erden, E. Modifying of cotton fabric surface with nano-ZnO multilayer films by layer-by-layer deposition method. Nanoscale Res. Lett. 2010, 5, 1204-1210. [CrossRef]

43. Shah, A.; Yameen, M.A.; Fatima, N.; Murtaza, G. Chemical synthesis of chitosan/silver nanocomposites films loaded with moxifloxacin: Their characterization and potential antibacterial activity. Int. J. Pharm. 2019, 561, 19-34. [CrossRef] [PubMed]

44. Ahmed, S.; Saifullah; Ahmad, M.; Swami, B.L.; Ikram, S. Green synthesis of silver nanoparticles using Azadirachta indica aqueous leaf extract. J. Radiat. Res. Appl. 2016, 9, 1-7. [CrossRef]

45. Shah, A.; Ashames, A.A.; Buabeid, M.A.; Murtaza, G. Synthesis, in vitro characterization and antibacterial efficacy of moxifloxacinloaded chitosan-pullulan-silver-nanocomposite films. J. Drug Deliv. Sci. Technol. 2020, 55, 101366. [CrossRef]

46. Mehrabi, F.; Shamspur, T.; Mostafavi, A.; Hakimi, H.; Mohamadi, M. Inclusion of sulfamethoxazole in a novel CuFe $\mathrm{O}_{4}$ nanoparticles/mesoporous silica-based nanocomposite: Release kinetics and antibacterial activity. Appl. Organomet. Chem. 2020, 35, 6035. [CrossRef]

47. Aseichev, A.V.; Azizova, O.A.; Beckman, E.M.; Skotnikova, O.I.; Dudnik, L.B.; Shcheglovitova, O.N.; Sergienko, V.I. Effects of Gold Nanoparticles on Erythrocyte Hemolysis. Bull. Exp. Biol. Med. 2014, 156, 495-498. [CrossRef] [PubMed] 